\title{
Synthesis and photovoltaic properties of two-dimensional conjugated polythiophenes with bi(thienylenevinylene) side chains
}

\author{
Jianhui Hou ${ }^{1,2}$, Zhan'ao Tan ${ }^{1,2}$, Yong Yan ${ }^{1}$, Youjun He ${ }^{1}$, Chunhe Yang ${ }^{1}$, Yongfang Li $^{1}$ * \\ 1. CAS Key Laboratory of Organic Solids, Center for Molecular Science, Institute of Chemistry, Chinese \\ Academy of Sciences, Beijing 100080, China \\ 2. Graduate School of Chinese Academy of Sciences, Beijing 100039, China
}

*Corresponding author. E-mail: liyf@iccas.ac.cn; Fax: 86-10-62559373.

\section{Experimental details}

Materials. $\quad n$-Butyllithium $2.88 \mathrm{~mol} / \mathrm{L}$ in hexane (Alfa Asia Chemical Co. ) and $\mathrm{Pd}\left(\mathrm{PPh}_{3}\right)_{4}$ ( Aldrich Chemical Co.) were used as received. Tetrahydrofuran (THF) was dried over $\mathrm{Na} /$ benzophenone ketyl and freshly distilled prior to use. N-carbaldehyde-piperidine, 1-bromo-dodecane and thiophene were dried over molecular sieves and freshly distilled prior to use. 2,5-Dibromo-3-bromomethyl-thiophene was synthesized with the procedure used previously ${ }^{1}$. The regioregular poly(3-hexylthiophene) (P3HT) was synthesized and purified according to the method reported in literatuer ${ }^{2}$, and the P3HT sample obtained possesses regioregularity of more than 95\%, number average molecular weight of $19 \mathrm{~K}$, and polymerization dispersity of $1.7 .{ }^{1} \mathrm{H} \mathrm{NMR}\left(\delta / \mathrm{ppm}, \mathrm{CDCl}_{3}\right): \quad 6.99(\mathrm{~s}, 1 \mathrm{H}), 2.79(\mathrm{t}, 2 \mathrm{H}), 1.72(\mathrm{~m}$, 2H), $1.34(\mathrm{~m}, 5 \mathrm{H}), 0.90(\mathrm{t}, 3 \mathrm{H})$. Elemental analysis: $\mathrm{C}=72.16 \%, \mathrm{H}=8.60 \%, \mathrm{~S}=19.21 \%$.

\footnotetext{
${ }^{1}$ Hou, J. H.; Yang, C. H.; Li, Y. Synth. Met. 2005, 153, 93.

${ }^{2}$ Robert S. Loewe, Paul C. Ewbank, Jinsong Liu, Lei Zhai, and Richard D. McCullough, Macromolecules, 2001, 34, $4324-4333$. 
$\mathrm{Br}<0.3 \%$. PCBM was synthesized using the method reported by Wudl et $\mathrm{al}^{3}$. MALDI-TOF Ms:

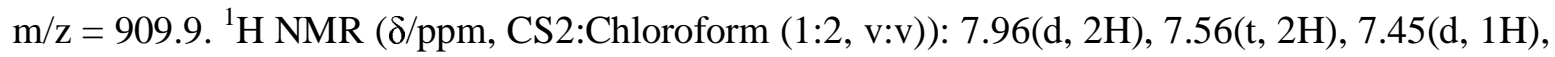
3.61(s, 3H), 2.82(t, 2H), 2.42(t, 2H), 2.08(m, 2H).

Characterization. ${ }^{1} \mathrm{H}$ NMR spectra were measured on a Bruker DMX-300 spectrometer. Absorption spectra were taken on a Hitachi U-3010 UV-Vis spectrophotometer. Photoluminescence spectra were measured using a Hitachi F-4500 spectrophotometer. The molecular weight of polymers was measured by GPC method, and polystyrene was used as a standard. TGA measurement was performed on a Perkin-Elmer TGA-7. The electrochemical cyclic voltammetry was conducted on a Zahner IM6e Electrochemical Workstation with Pt disk coated with the polymer film, Pt plate, and $\mathrm{Ag} / \mathrm{Ag}^{+}$electrode as working electrode, counter electrode and reference electrode respectively in a $0.1 \mathrm{~mol} / \mathrm{L}$ tetrabutylammonium hexafluorophosphate $\left(\mathrm{Bu}_{4} \mathrm{NPF}_{6}\right)$ acetonitrile solution.

\section{Fabrication and characterization of polymer solar cells}

Polymer solar cells (PSCs) were fabricated with the structure of ITO/PEDOT:PSS/Polymer:PCBM/Mg/Al. The ITO glass was pre-cleaned and modified by a thin layer of PEDOT:PSS (Bayer) which was spin-cast from a PEDOT:PSS aqueous solution on the ITO substrate, and was dried subsequently at $150{ }^{\circ} \mathrm{C}$ for $10 \mathrm{~min}$ in a vacuum oven. The thickness of the PEDOT: PSS layer was about $30 \mathrm{~nm}$. The photosensitive blend layer of polymer and PCBM was prepared by spin-coating the chlorobenzene solution of the polymers and PCBM $(1: 1 . \mathrm{w} / \mathrm{w})$ with the polymer concentration of $10 \mathrm{mg} / \mathrm{ml}$ on the ITO/PEDOT:PSS electrode, and dried at $80{ }^{\circ} \mathrm{C}$ for $30 \mathrm{~min}$. The thickness of the photosensitive layer was controlled to ca. $80 \mathrm{~nm}$ by adjusting the rotating speed of the spin-coating, and was measured on an Ambios Tech. XP-2

\footnotetext{
${ }^{3}$ Jan C. Hummelen, Brian W. Knight, F. LePeq, and Fred Wudl, J. Org. Chem. 1995, 60, 532-538
} 
profilometer. Then the metal cathode, which is made up of $\mathrm{Mg}$ and $\mathrm{Al}$, was deposited on the polymer layer by vacuum evaporation under $5 \times 10^{-5} \mathrm{~Pa}$. The $\mathrm{Mg}$ layer was deposited by a speed of $0.03-0.05 \mathrm{~nm}$ per second, and the thickness of which is $10 \mathrm{~nm}$. Then, the Al layer was deposited by a speed of $0.1-0.3 \mathrm{~nm}$ per second, and the thickness of which is $150 \mathrm{~nm}$. Five PSC devices were fabricated for each polymer samples in the experiment, and the effective area of one cell is $4 \mathrm{~mm}^{2}$.

The current-voltage (I-V) measurement of the devices was conducted on a computer-controlled Keithley 236 Source Measure Unit. A Xenon lamp with AM1.5 filter was used as the white light source, and the optical power at the sample was $100 \mathrm{~mW} / \mathrm{cm}^{2}$. The input photon to converted current efficiency (IPCE) was measured using a Keithley 2000 DMM coupled with WDG3 monochromator and $500 \mathrm{~W}$ Xenon lamp. The light intensity at each wavelength was calibrated with a standard single-crystal Si photovoltaic cell.

\section{Synthesis}

2-Chloromethyl-thiophene. 1. $16.8 \mathrm{~g}(0.20 \mathrm{~mol})$ thiophene and $60 \mathrm{ml}$ concentrated hydrochloric acid were put into a flask. Then pre-dried hydrogen chloride was rapidly bubbled into the solution till saturated, which resulted in temperature increase of the solution. Under ice/salt bath, $20 \mathrm{ml}(0.2 \mathrm{~mol})$ of formaldehyde solution $(35 \%)$ was added dropwise at temperature below $0^{\circ} \mathrm{C}$. After the addition of formaldehyde, the reaction was kept for 20 min under stirring. The mixture was poured into ice-water, and then extracted by ether. The organic layer was collected, washed by water and dried over anhydrous $\mathrm{MgSO}_{4}$. Then distillation was performed under vacuum, and the water-white liquid of compound $\mathbf{1}$ was obtained $(11.1 \mathrm{~g}$, yield $42 \%)$ 
GC-Ms: $\mathrm{m} / \mathrm{z}=132 .{ }^{1} \mathrm{H}$ NMR $\left(\delta / \mathrm{ppm}, \mathrm{CDCl}_{3}\right): 6.91(\mathrm{~d}, 1 \mathrm{H}), 6.72(\mathrm{t}, 1 \mathrm{H}), 6.58(\mathrm{~d}, 1 \mathrm{H}), 4.64(\mathrm{~s}$, $2 \mathrm{H})$.

2-Dodecyl-thiophene, 2. Thiophene $(8.4 \mathrm{~g}, 0.10 \mathrm{~mol})$ was dissolved in $60 \mathrm{ml}$ THF in a well-dried flask under the protection of $\mathrm{N}_{2} . \mathrm{n}$-Butyl lithium $(35 \mathrm{ml}, 0.10 \mathrm{~mol}, 2.88 \mathrm{~mol} / \mathrm{L}$ in hexane) was added dropwise. After 1 hour, 1-bromododecane (22.6 g, 0.20 mol) was added in one portion. The solution was stirred overnight, and then it was poured into $200 \mathrm{ml}$ cool water. The organic layer was separated, and the aqua layer was extracted by ether. The organic layers were collected, washed with water, and dried over anhydrous $\mathrm{MgSO}_{4}$, the removal of solvent gave a crude product. Distillation of the crude product under vacuum gave $18 \mathrm{~g}$ (0.07 mol, yield 70\%) of 2-dodecyl-thiophene.

GC-Ms: m/z = 252. ${ }^{1} \mathrm{H}$ NMR $\left(\delta / p p m, \mathrm{CDCl}_{3}\right): 6.91(\mathrm{~d}, 1 \mathrm{H}), 6.72(\mathrm{t}, 1 \mathrm{H}), 6.60(\mathrm{~d}, 1 \mathrm{H}), 2.75(\mathrm{t}$, 2H), 1.69 (p, 2H), 1.40-1.10 (m, 18H), $0.92(\mathrm{t}, 3 \mathrm{H})$.

5-Dodecyl-thiophene-2-carbaldehyde, 3. 5-Dodecyl-thiophene-2-carbaldehyde was prepared by the same procedure as that in the synthesis of Compound 2, except that Compound 2 (12.6 $\mathrm{g}$, $50 \mathrm{mmol})$ and $\mathrm{N}$-carbaldehyde-piperidine $(11.3 \mathrm{~g}, 0.10 \mathrm{~mol})$ were used instead of thiophene and 1-bromo-dodecane. Purification was carried out via silica gel column chromatography, using petroleum ether/ ethyl acetate $(20: 1, \mathrm{Vol} / \mathrm{Vol})$ as the eluent. After removing of solvent, $9.1 \mathrm{~g}$ (32.5 mol, yield 65\%) of 5-dodecyl-thiophene-2-carbaldehyde was obtained.

GC-Ms: $\mathrm{m} / \mathrm{z}=280 .{ }^{1} \mathrm{H}$ NMR $\left(\delta / \mathrm{ppm}, \mathrm{CDCl}_{3}\right): 9.79(\mathrm{~s}, 1 \mathrm{H}), 7.58(\mathrm{~d}, 1 \mathrm{H}), 6.86(\mathrm{~d}, 1 \mathrm{H}), 2.83(\mathrm{t}$, 2H), $1.67(\mathrm{p}, 2 \mathrm{H}), 1.40-1.15(\mathrm{~m}, 18 \mathrm{H}), 0.85(\mathrm{t}, 3 \mathrm{H})$.

2-((E)-2-(5-dodecylthiophen-2-yl)vinyl)thiophene, 4. 2-chloromethyl-thiophene $(2.65 \mathrm{~g}, 20$ mmol) and Phosphorous acid triethyl ester (3.32 g, $20 \mathrm{mmol})$ were put in a flask, and heated to $160^{\circ} \mathrm{C}$ for $2 \mathrm{~h}$ to get the product of (thiophen-2-ylmethyl)-phosphonic acid diethyl ester. Then 
the product was dissolved in $30 \mathrm{ml}$ dried DMF. Under a cool-water bath, $\mathrm{NaOCH}_{3}(1.2 \mathrm{~g}$ in 20 $\mathrm{ml}$ DMF) was added into the solution. Then Compound 3 (5.6 g, $20 \mathrm{mmol})$ was added dropwise to the solution. After $30 \mathrm{~min}$, the solution was poured into water, and extracted with ether. The organic layer was collected, washed with water and then dried over anhydrous $\mathrm{MgSO}_{4}$, filtered, and concentrated. Purification was carried out via silica gel column chromatography, using petroleum ether as the eluent. A white solid of Compound $\mathbf{4}$ was obtained after the purification(5.6 g, yield 78\%).

GC-Ms: m/z = 360. ${ }^{1} \mathrm{H}$ NMR $\left(\delta / p p m, \mathrm{CDCl}_{3}\right): 7.16(\mathrm{~d}, 1 \mathrm{H}), 7.01(\mathrm{~s}, 2 \mathrm{H}), 6.97(\mathrm{~d}, 1 \mathrm{H}), 6.95(\mathrm{~s}$, $1 \mathrm{H}), 6.83(\mathrm{~d}, 1 \mathrm{H}), 6.64(\mathrm{~d}, 1 \mathrm{H}), 2.78(\mathrm{t}, 2 \mathrm{H}), 1.68(\mathrm{p}, 2 \mathrm{H}), 1.33-1.10(\mathrm{~m}, 18 \mathrm{H}), 0.89(\mathrm{t}, 3 \mathrm{H})$. Elemental analysis: Calculated for $\mathrm{C}_{22} \mathrm{H}_{32} \mathrm{~S}_{2}$ : C, 73.27; H, 8.94; S, 17.78; found: C, 73.22; H, $8.89 ; \mathrm{S}, 17.32$.

5-((E)-2-(5-dodecylthiophen-2-yl)vinyl)thiophene-2-carbaldehyde, 5. This compound was synthesized by the same procedure as that used in synthesizing Compound $\mathbf{3}$, except that Compound 4 was used instead of Compound 2. After recrystallization from hexane, a pale yellow solid of Compound 5 was obtained (yield 82\%).

GC-Ms: $\mathrm{m} / \mathrm{z}=388 .{ }^{1} \mathrm{H}$ NMR $\left(\delta / \mathrm{ppm}, \mathrm{CDCl}_{3}\right): 9.85(\mathrm{~s}, 1 \mathrm{H}), 7.62(\mathrm{~d}, 1 \mathrm{H}), 7.19(\mathrm{~d}, 1 \mathrm{H}), 7.07(\mathrm{~d}$, 1H), $6.95(\mathrm{~d}, 1 \mathrm{H}), 6.87(\mathrm{~d}, 1 \mathrm{H}), 6.69(\mathrm{~d}, 1 \mathrm{H}), 2.79(\mathrm{t}, 2 \mathrm{H}), 1.67(\mathrm{p}, 2 \mathrm{H}), 1.33-1.10(\mathrm{~m}, 18 \mathrm{H}), 0.88$ (t, 3H). Calculated for $\mathrm{C}_{23} \mathrm{H}_{32} \mathrm{OS}_{2}: \mathrm{C}, 71.08 ; \mathrm{H}, 8.30 ; \mathrm{S}, 16.50$; found: C, 71.12; H, 8.32; S, 16.43

\section{2,5-dibromo-3-((1E)-2-(5-((E)-2-(5-dodecylthiophen-2-yl)vinyl)thiophen-2-yl)vinyl)thiophen}

e, 6. 2,5-dibromo-3-bromomethyl-thiophene $(3.35 \mathrm{~g}, 10 \mathrm{mmol})$ and Phosphorous acid triethyl ester $(1.66 \mathrm{~g}, 10 \mathrm{mmol})$ were put in a flask, and heated to $160^{\circ} \mathrm{C}$ for $2 \mathrm{~h}$ to get the product of (2,5-Dibromo-thiophen-3-ylmethyl)-phosphonic acid diethyl ester. Then the product and 
compound $5(0.01 \mathrm{~mol})$ were dissolved in $50 \mathrm{ml}$ dried DMF. Under a cool-water bath, $\mathrm{NaOCH}_{3}$ (0.6 $\mathrm{g}$ in $10 \mathrm{ml} \mathrm{DMF}$ ) was added into the solution. After $30 \mathrm{~min}$, the solution was poured into water, and extracted with chloroform. The organic layer was collected, washed with water and then dried over anhydrous $\mathrm{MgSO}_{4}$, filtered, and concentrated. A yellow solid of Compound 6 was obtained (4.26 g, yield 68\%) after purification by recrystallization from hexane .

GC-Ms: $\mathrm{m} / \mathrm{z}=624 .{ }^{1} \mathrm{H}$ NMR $\left(\delta / \mathrm{ppm}, \mathrm{CDCl}_{3}\right): 7.14(\mathrm{~s}, 1 \mathrm{H}), 7.00-6.64(\mathrm{~m}, 8 \mathrm{H}), 2.79(\mathrm{t}, 2 \mathrm{H})$, $1.67(\mathrm{p}, 2 \mathrm{H}), 1.33-1.10(\mathrm{~m}, 18 \mathrm{H}), 0.89$ (t, 3H). Calc. for $\mathrm{C}_{28} \mathrm{H}_{34} \mathrm{Br}_{2} \mathrm{~S}_{3}$ : C, 53.67; H, 5.47; Br, 25.51; S, 15.35. Found: C, 53.58; H, 5.62; Br, 25.34; S, 15.22 .

2,5-Bis(tributylstannyl)thiophene. Thiophene $(8.4 \mathrm{~g}, 0.10 \mathrm{~mol})$ was dissolved in $60 \mathrm{ml}$ THF in a well-dried flask under the protection of nitrogen. n-Butyl lithium (76 ml, $0.22 \mathrm{~mol}$, $2.88 \mathrm{~mol} / \mathrm{L}$ in hexane) was added dropwise, (caution: a great deal of gas evolved.) and the solution was stirred under reflux for 2 hours. After being cooled down to ambient temperature, tributylchlorostannane $(70 \mathrm{~g}, 0.21 \mathrm{~mol})$ was added in one portion. After 12 hours, the solution was poured into $100 \mathrm{ml}$ cool water. The organic layer was separated, and the aqua layer was extracted by ether. The organic layers were collected and dried over anhydrous $\mathrm{MgSO}_{4}$, the removal of solvent gave a crude product. After distillation under vacuum $\left(0.1 \mathrm{mmHg} / 220^{\circ} \mathrm{C}\right), 35$ g (0.053 mol, yield 53\%) of 2,5-Bis(tributylstannyl)thiophene was obtained.

Purity (by GC) >96\%. GC-Ms: m/z = 664. ${ }^{1} \mathrm{H}$ NMR ( $\left.\delta / \mathrm{ppm}, \mathrm{CDCl}_{3}\right): 7.34(\mathrm{~s}, 2 \mathrm{H}), 1.60(\mathrm{~m}$, 12H), $1.39(\mathrm{~m}, 12 \mathrm{H}), 1.09(\mathrm{~m}, 12 \mathrm{H}), 0.91(\mathrm{t}, 18 \mathrm{H})$.

Synthesis of P1, P2 and P3 using Stille coupling reaction. These three polymers were prepared with a same procedure of coupling 2,5-dibromo-3-substituted-thiophenes with 2,5-bis(tributylstannyl)-thiophene. 
$1.0 \mathrm{mmol}$ of the mixture of 2,5-dibromo-3-hexyl-thiphene and compound $\mathbf{6}$ was put into a three-neck flask. The content of each component in the mixture was controlled with different values for the preparation of different polymers, as shown in Table S1. Then, $15 \mathrm{ml}$ of degassed toluene was added under the protection of argon. The solution was flushed with argon for 10 min, and then $50 \mathrm{mg}$ of $\mathrm{Pd}\left(\mathrm{PPh}_{3}\right)_{4}$ and $1.0 \mathrm{mmol}$ of 2,5-bis(tributylstannyl)-thiophene were added. After another flushing with argon for $20 \mathrm{~min}$, the reactant was heated to reflux for 12 hours. Then the reactant was cooled to room temperature, and the polymer was precipitated by addition of $50 \mathrm{ml}$ methanol, and filtered through a Soxhlet thimble, which was then subjected to Soxhlet extraction with methanol, hexane, and chloroform. The polymer was recovered as a solid sample from the chloroform fraction by rotary evaporation. The solid was dried under vacuum for 1 day to ge the final product. The yields of the polymerization reactions were about $40-50 \%$.

Table S1. The content of monomers in Stille coupling reaction \& the elemental analysis and molecular weight of the biTV-PTs.

\begin{tabular}{|c|c|c|c|c|c|c|c|c|c|}
\hline & \multicolumn{3}{|c|}{ Amounts of monomers (mmol) } & \multicolumn{3}{|c|}{ Elemental analysis $(\%)$} & \multirow{3}{*}{$\mathrm{m}: \mathrm{n}^{\mathrm{a}}$} & \multicolumn{2}{|c|}{ Molecular weight } \\
\hline & Compound & 2,5-Dibromo-3- & 2,5-Bis(tributylsta & & & & & $M_{\mathrm{n}}$ & $\mathrm{DP}$ \\
\hline & 6 & hexylthiophene & nnyl)-thiophene & $\mathrm{C}$ & $\mathrm{H}$ & $S$ & & & \\
\hline P1 & 1 & 0 & 1 & 69.11 & 6.43 & 23.32 & $1: 0$ & $21 \mathrm{~K}$ & 2.30 \\
\hline $\mathrm{P} 2$ & 0.5 & 0.5 & 1 & 68.30 & 6.02 & 23.96 & 0.99 & $48 \mathrm{~K}$ & 1.34 \\
\hline P3 & 0.2 & 0.8 & 1 & 67.10 & 5.99 & 24.23 & 0.59 & $50 \mathrm{~K}$ & 1.62 \\
\hline
\end{tabular}

\footnotetext{
${ }^{\mathrm{a}}$ This value was determined by ${ }^{1} \mathrm{H}$ NMR spectra.
} 